\title{
An Analysis of Gender Differences in Intra-household Time Allocation of Rural Farm Families in Sri Lanka
}

\author{
R.M.S.D. Rathnayaka* and J. Weerahewa ${ }^{1}$ \\ Postgraduate Institute of Agriculture \\ University of Peradeniya \\ Sri Lanka
}

\begin{abstract}
Households are the locus of much economic decision-making. Of the resources endowed by the household, the time resource plays a crucial role in determining wellbeing of the individual members of the household. The objectives of this study were to describe the gender differences in time allocation within the rural households, and to find out the determinants of the time allocations for nonpaid activities. The rules regarding allocation of resources within the household were captured using collective model. It was hypothesized that each spouse makes decisions within his or her own sphere and responds to the other's decisions by altering their own level of voluntary contribution to shared goods. An empirical model was specified, treating hours spent on nonpaid work by each spouse as the dependent variable and individual, household characteristics, and partner's time allocation as independent variables. They were estimated simultaneously using the two-stage least square (2SLS) technique. Data were extracted from the baseline survey carried out among rural households in Udukumbara village in Kandy district. The results reveal that husbands allocate more hours to both paid and nonpaid work and fewer hours to care work than the wives. According to 2SLS estimation results, total land extent and education level have significant positive and negative effects, respectively on nonpaid work hours of both spouses. The presence of other adults in the household has a negative and significant effect on wives' nonpaid working hour. Interestingly, the results indicate that nonpaid work hours of one spouse have a significant negative effect on the other's nonpaid work, indicating the members jointly make time allocation decisions.
\end{abstract}

Keywords: Collective model, gender differences, intra-household, time allocation

\section{INTRODUCTION}

Households are the locus of most economic decision-making. Households function as producers, investors, managers of risk and as consumers. Different types of resources are endowed by the households and are allocated among various production activities. Of the resources, time plays a crucial role in determining the wellbeing of individual members. Time is a scarce resource. Time allocation to various activities is influenced by both economic and noneconomic factors, and gender is one such factor (Kes and Swaminathan, 2006). Time allocation to different activities by women and men and, in particular, the gender division of household labour, is a useful indicator of social change (Baxter and Hewitt, 2013). Increasingly, time-use analyses are being used to address various research

1 Department of Agricultural Economics and Business Management, Faculty of Agriculture, University of Peradeniya

Corresponding author: peradeniyajeevikaw@pdn.ac.lk 
issues with respect to family welfare (Offer and Schneider, 2011; Gimenez-Nadal and Sevilla, 2012).

A number of studies have found that gender inequalities exist in time use (Connelly and Kimmel, 2009, Gwozdz and Sousa-Poza, 2010 \& Burda et al. 2013). Ilahi (2000), discussed the composition of male-female time tasks, explained that women work more than men in almost all regions. Further, Evers and Walters (2001) and Sow (2010) revealed that women in rural farm families supply the majority of the labour for food production, processing, and household chores, including care work, while men divide their time mainly between farm work and leisure, with minimal assistance to women in domestic work.

Adequate knowledge of the nature of time allocation within rural families is imperative when designing public policies that target improvement in the wellbeing of rural families (Diksha and Codrina, 2013). However, as shown by the literature, little or no attempt has been made by researchers in Sri Lanka to examine the differences in time allocations of males and females in households and to analyze the determinants of time allocation for different tasks. This study, therefore, attempted to fill the research gap by studying the gender differences in time allocation and by analysing the determinants of time allocation within rural farm families.

\section{METHODOLOGY}

\section{Study area and data collection}

Udukumbura is a remote village located at Udadumbara divisional secretariat in Kandy district. It is characterized by traditional home gardens, which are rich in agro-biodiversity. Paddy cultivation, vegetable cultivation and palm tapping are the main livelihood activities in the area. Semi-subsistence households are predominant in the village and they cultivate paddy, field crops and vegetables for their own consumption, and sell the surplus, if any. The majority of the households in the village cultivates pepper and other Kandyan spices and sells them in the market, which is far from the village. This village can be considered as an isolated village in Kandy district, with poor infrastructure facilities including education, health and market access.

As a component of the project activity 'Biodiversity for Food and Nutrition Security in Sri Lanka' carried out by the Faculty of Agriculture, University of Peradeniya, a baseline survey was conducted in Udukumbura village using a structured questionnaire. Of the 92 families living in the area, responses were gathered from 80 wives and husbands on the time-use data, individual characteristics of members, and household characteristics. A typical day was divided into three sections to obtain time use data: paid work, nonpaid work and care work. Paid work includes time dedicated to regular and irregular employment. Nonpaid work consists of work in a home garden, crop field, chena and extracting from the forest. Lastly, cooking, child care and other (cleaning, housework and washing laundry) were considered as care work of the household. The above dataset was used in estimating the following models.

\section{Model: Theoretical and empirical approach}

Economic theory of time allocation within the household was initiated by Becker (1965), and his approach treats the family as a single decision-making agent, with a single pooled budget constraint and a single utility function. This theory was subjected to considerable criticism 
later. In response to the shortcomings of the Becker model, Chiappori (1988) developed a model assuming that each spouse makes decisions within his or her own sphere, and responds to the other's decisions by altering the level of voluntary contribution to shared goods. Taking into account this collective model for intra-household resource allocation and previous time use studies, time use decision of each spouse is considered as a function of individual characteristics, household characteristics and a partner's time use decision.

The hours spent on nonpaid works by each spouse were regressed with individual characteristics, household characteristics and partner's nonpaid time allocation. Age and education level were considered as individual characteristics and the total land extent, presence of young children, presence of other adults and the social role of the family were included as household characteristics into the model. Social role was measured, giving the scores for each household based on their memberships and positions in farmer organizations, religious societies and other social organizations in the village.

Equation used for husband's time allocation

HNPWH $=\alpha_{0}+\alpha_{1}$ WNPWH $+\alpha_{2}$ HAGE $+\alpha_{3}$ HEDL $+\alpha_{4}$ YCHILD $+\alpha_{5}$ ADLT $+\alpha_{6}$ SRL + $\alpha_{7} \mathrm{LEXT}+\varepsilon \mathrm{i}$

Equation for wife's time allocation

$\mathrm{WNPWH}=\beta_{0}+\beta_{1} \mathrm{HNPWH}+\beta_{2} \mathrm{WAGE}+\beta_{3} \mathrm{WEDL}+\beta_{4}$ YCHILD $+\beta_{5} \mathrm{ADLT}+\beta_{6} \mathrm{SRL}+$ $\beta_{7} \mathrm{LEXT}+\varepsilon \mathrm{i}$

Where, $\alpha_{0}$ to $\alpha_{7}$ and $\beta_{0}$ to $\beta_{7}=$ coefficient $\quad \varepsilon i=$ error term

Table 1. Description of variables for empirical model

\begin{tabular}{lll}
\hline Variable & Description of the variable & Units \\
\hline HNPWH & Nonpaid work hours of husband & $\%$ \\
WNPWH & Nonpaid work hours of wife & $\%$ \\
HAGE & Age of husband & Years \\
WAGE & Age of wife & Years \\
HEDL & Education level of husband & No. of years of schooling \\
WEDL & Education level of wife & No. of years of schooling \\
LEXT & Land extent & Acres \\
YCHILD & Presence of young children & If yes $=1$, otherwise $=0$ \\
ADLT & Presence of other adult & If yes $=1$, otherwise $=0$ \\
SRL & Social role & Scale \\
\hline
\end{tabular}

In the above two equations, the two endogenous variables, the nonpaid working hours of husband and wife (HNPWH and WNPWH) were calculated by summing up the hours they spent in the home garden, crop field, chena and extracting from forests. LEXT, YCHILD, ADLT and SRL are household characteristics, which are common for both husband and wife. Age and education level are individual characteristics of each partner and WAGE and WEDL are used as instrumental variables for WNWH when estimating HNPWH and viceversa. 
The two-stage least squares (2SLS) technique was used to estimate the two equations simultaneously using stata11. 2SLS has been a widely used method of estimating the parameters of a system of linear simultaneous equations. As stated by Wooldridge (2008), in the first step of the 2SLS, the endogenous variable should be regressed against the instrument variable(s) plus all exogenous variables appearing in the model. Using this predicted value of the endogenous variable, the resulting equation can be estimated by the ordinary least squares (OLS) technique. The instrumental variable/s should be uncorrelated with the error term in the equation, and should be correlated with the endogenous explanatory variables.

\section{RESULTS AND DISCUSSION}

\section{General characteristics of the sample}

The household characteristics of the sample and gender differences in time allocation within the rural households are presented in Tables 2 and 3, respectively. It is evident that, on average, husbands are older than wives and wives are relatively more educated than husbands. An average household owns around one acre each of lowland and highland.

\section{Table 2. General characteristics of households}

\begin{tabular}{llccc}
\hline Variable & Unit & Average & Minimum & Maximum \\
\hline Age of husband & Years & 50 & 24 & 76 \\
Age of wife & Years & 42 & 19 & 72 \\
Education level of husband & Schooling years & 5 & 0 & 13 \\
Education level of wife & Schooling years & 6 & 0 & 13 \\
Extent of home garden & Acres & 1.5 & 0.5 & 5 \\
Extent of chena & Acres & 0.5 & 0 & 5 \\
Extent of lowland & Acres & 1.1 & 0 & 5 \\
Extent of upland & Acres & 1.2 & 0 & 4.5 \\
Total household income & LKR & 14909 & 0 & 48583 \\
Social role & Scale & 2.2 & 0 & 4 \\
\hline
\end{tabular}

Table 3 shows the summary of time allocation for different tasks, i.e., paid works, nonpaid works and care works by husbands and wives. It is evident that husbands allocate more time for nonpaid works and wives allocate more time for care works. The allocation between paid regular employment and irregular employment by both spouses is equal. Nonpaid work includes time devoted for working in the home garden, crop field and chena and extractions from forests. Husbands work longer hours in all of the above activities compared to those by wives. Care works include cooking, childcare and other works in the home, and wives allocate a lot more time for childcare than husbands. However, the total workday is longer for women than men. 
Table 3. Time allocation of husbands and wives (hours/day)

\begin{tabular}{lllll}
\hline \multirow{2}{*}{ Activity } & \multicolumn{2}{l}{ Husband (hrs.) } & \multicolumn{2}{l}{ Wife (hrs.) } \\
\cline { 2 - 5 } & Mean & Std. Dev & Mean & Std. Dev \\
\hline Paid works - Subtotal & $\mathbf{3 . 3 6}$ & $\mathbf{4 . 6 5}$ & $\mathbf{2 . 1 0}$ & $\mathbf{4 . 2 3}$ \\
Paid regular employment & 4.17 & 5.51 & 1.07 & 3.45 \\
Paid irregular employment & 5.24 & 4.62 & 1.10 & 2.90 \\
Nonpaid works - Subtotal & $\mathbf{1 0 . 5 8}$ & $\mathbf{5 . 8 7}$ & $\mathbf{5 . 9 3}$ & $\mathbf{4 . 7 8}$ \\
Nonpaid home garden & 4.10 & 3.26 & 3.26 & 2.55 \\
Nonpaid crop field & 7.04 & 4.05 & 3.20 & 4.01 \\
Nonpaid chena & 3.40 & 3.02 & 0.61 & 1.86 \\
Extracts from forest & 0.72 & 0.71 & 0.28 & 0.46 \\
Care works - Subtotal & $\mathbf{0 . 7 8}$ & $\mathbf{2 . 2 5}$ & $\mathbf{6 . 8 0}$ & $\mathbf{5 . 3 1}$ \\
Cooking & 1.36 & 1.46 & 3.01 & 1.52 \\
Childcare & 1.93 & 4.00 & 7.33 & 4.87 \\
Other & 0.28 & 0.72 & 0.89 & 1.87 \\
\hline
\end{tabular}

\section{Econometric estimation}

The results of the estimations of the two models using 2SLS are shown in Table 4. The results very clearly indicate that the allocation of time on nonpaid work by the spouse has a negative and statistically significant effect on the nonpaid time allocation of the partner. This implies that household members jointly make decisions on allocation of time for different works.

Table 4. 2SLS Estimators for spouses' nonpaid works allocation

\begin{tabular}{|c|c|c|c|c|}
\hline \multirow[t]{2}{*}{ Description of the variable } & \multicolumn{2}{|c|}{$\begin{array}{l}\text { Dependent Variable: } \\
\text { Nonpaid work allocation } \\
\text { of husband }\end{array}$} & \multicolumn{2}{|c|}{$\begin{array}{l}\text { Dependent Variable: } \\
\text { Nonpaid work } \\
\text { allocation of wife }\end{array}$} \\
\hline & Coefficient & $\begin{array}{l}\text { Standard } \\
\text { Error }\end{array}$ & Coefficient & $\begin{array}{l}\text { Standard } \\
\text { Error }\end{array}$ \\
\hline Constant & 12.1673 & 0.3524 & 8.040 & 3.0102 \\
\hline Spouse nonpaid working hours & $-0.1520 *$ & 0.0465 & $-0.2410 *$ & 0.0780 \\
\hline Age of the husband & -0.3506 & 0.0656 & n.a. & n.a. \\
\hline Age of the wife & n.a. & n.a. & -0.0680 & 0.0987 \\
\hline Education level of husband & $-0.4362 * *$ & 0.1876 & n.a. & n.a. \\
\hline Education level of wife & n.a. & n.a. & $-0.3898 *$ & 0.1380 \\
\hline Land extent & $0.8083 *$ & 0.3142 & $1.0505 *$ & 0.2087 \\
\hline Presence of young children & -1.4180 & 0.5810 & -0.9976 & 1.3560 \\
\hline Presence of other adult & -0.1832 & 1.6052 & $-1.386 * *$ & 0.2841 \\
\hline Social role & -0.5040 & 0.8788 & 0.0875 & 0.6860 \\
\hline Number of observations & 80 & & 80 & \\
\hline R-squared & 40.3 & & 65.09 & \\
\hline Probability $>\mathrm{Chi}^{2}$ & 0.000 & & 0.000 & \\
\hline Root MSE & 5.3457 & & 4.0567 & \\
\hline
\end{tabular}


Total land extent has a positive and statistically significant effect, and nonpaid work hours of both spouses indicate that those who own large extents of home garden, crop fields or chena spend more time in such lands rather than in engaging in paid work. Skoufias (1993) also found some similar results. He used the value of the family farm and the value of home as proxies for non-wage income and found that when the non-wage income increases, the male spouse allocates little time on regular and irregular paid work. The results reported in Table 4 also show that education level has a negative and statistically significant effect on nonpaid work hours of both husbands and wives, implying that more educated people devote less time to nonpaid work. Similar result was reported by Ilahi (2000).

The presence of other adults in the family, such as elderly parents of the wife and/or the husband, has a negative and statistically significant effect on the wife's nonpaid time. The effect of the same on husbands' time allocation on nonpaid work is statistically insignificant.

\section{CONCLUSIONS}

The study clearly shows that males in rural farming families in the Udukumbura area allocate more hours for both paid works and nonpaid works and fewer hours for care works. However, results showed that the total workday is longer for women than for men, and as a result, women have less leisure than men. According to the results of the econometric estimation, the total land extent has a positive significant effect on nonpaid working hours, indicating that those who have a large home garden, crop field or chena cultivation prefer to work more hours in the field than engage in paid works. This study reveals that educated individuals allocate less hours to nonpaid works. Education is an important indicator of human capital and that increases the returns to wage works, and greater education levels increase the paid work participation. Further, the presence of another adult has a negative significant effect on a wife's nonpaid working hours.

One striking finding of the study is that the nonpaid working hours of one spouse has a negative and statistically significant effect on the other's nonpaid works, implying that household members jointly make decisions on time allocation. This should be carefully considered in formulations of rural poverty alleviation projects and woman empowerment programs.

\section{ACKNOWLEDGEMENT}

The authors would like to extend their profound thanks to Professor DKNG Pushpakumara, leader of the project of 'Biodiversity for Food and Nutrition Security in Sri Lanka' and his project team for provision of the baseline data set for the investigation and for comments provided on the earlier version of the paper.

\section{REFERENCES}

Baxter, Janeen and Belinda Hewitt. (2013). Negotiating domestic labor: Women's earnings and housework time in Australia. Feminist Economics, 19(1), 29 - 53.

Becker, G.A. (1965). Theory of the allocation of time. The Economic Journal, 75, 493 - 517. 
Burda, M., Hamermesh, D.S. and Weil P. (2013). Total Work and Gender: Facts and Possible Explanations. Journal of Population Economics, 26(1), 239 - 261.

Chiappori, P.A. (1988). Rational household labor supply. Econometrica, 56, 63 - 89.

Connelly, R. and Kimmel, J. (2009). Spousal Influences on Parents' Non-market Time Choices. Review of Economics of the Household 7(4), 361 - 394.

Diksha Arora and Codrina Rada (2013). Gender differences in in time and resource allocation in rural households in Ethiopia. JEL Classification: D1, B540, 13.

Evers, B. and Walters, B. (2001). The Model of a Gender-Segregated Low-Income Economy Reconsidered: Evidence from Uganda. Review of Development Economics, 5(1), 76 - 88.

Gimenez-Nadal, Jose Ignacio and Almudena Sevilla. (2012). Trends in time allocation: A cross-country analysis. European Economic Review 56(2012), 1338 - 1359.

Gwozdz, W. and Sousa-Poza A. (2010). Explaining Gender Differences in Housework Time in Germany. Journal of Consumer Policy, 33(2), 183 - 200.

Ilahi N (2000). The Intra-household Allocation of Time and Tasks: What Have We Learnt from the Empirical Literature? The World Bank Development Research Group/ Poverty Reduction and Economic Management Network Policy Research Report on Gender and Development Working Paper Series No. 13. 29(2), 471 - 522.

Kes A, Swaminathan H (2006). Gender and Time Poverty in sub-Saharan Africa. World Bank Working Paper No 73.

Offer, Shira and Barbara Schneider. (2011). Revisiting the Gender Gap in Time-use Patterns: Multitasking and well-being among mothers and fathers in dual-earner families. American Sociological Review, 76(6), 809 - 833.

Skoufias, Emmanuel (1993). Labor Market Opportunities and Interfamily Time Allocation in Rural Households in South Asia. Journal of Development Economics, 4O(2), 277 - 310.

Sow, F.D. (2010). Intra household resource allocation and well-being: The case of rural households in Senegal. PhD thesis, Wageningen University.

Wooldridge M. (2008). Introductory Econometrics, A Modern Approach. Second Edition, March 27th 2008, Cengage Learning. 